\title{
Effect of Controlled Atmosphere Storage (CAS) on Phosphofructokinase Activity in Mango (Mangifera indica L.) cv. Keitt
}

\author{
A.A. Elhefny, S.G. Gyulakhmedov, S.M. El-Hefnawi ${ }^{1}$, \\ M.M. Gad ${ }^{1}$, and A.A. Kuliyev \\ Department of Biochemistry and Biotechnology, Faculty of Biology, \\ Baku State University, Azerbaijan. \\ ${ }^{1}$ Horticulture Department, Faculty of Agriculture, \\ Zagazig University, Egypt.
}

\begin{abstract}
A controlled atmosphere (CA) is an agricultural storage method. It is an atmosphere in which oxygen, carbon dioxide and nitrogen concentration as well as temperature and humidity are regulated. Glycolysis is the basis of both anaerobic respiration and aerobic respiration, and it occurs in nearly all organisms. It is regulated by three enzymes catalyzing nonequilibrium reactions: Hexokinase, phosphofructokinase, and pyruvate kinase.

In this work we studied the effect of controlled atmosphere storage (CAS) of mango at $13^{\circ} \mathrm{C}$ on the activity of phosphofructokinase (PFK) and on fruit quality. This study was carried out on mango fruits (Mangifera indica L.) cv. Keitt. The storage of fruits under the CA retarded ripening and did not affect the quality attributes of Keitt mango. There was a significant decreasing in the activity of PFK as compared with control under (CAS) used in this work. These results indicate a potential for the application of CA for postharvest ripening control of mango. The optimal CA for longterm storage of "Keitt" mango at $13{ }^{\circ} \mathrm{C}$ is $\left(3 \% \mathrm{O}_{2}+6 \% \mathrm{CO}_{2}+91 \% \mathrm{~N}_{2}\right)$; under these conditions the storage life of mango can be extended up to 10 weeks.
\end{abstract}

Keywords: Controlled atmosphere storage, mango, anaerobic respiration, aerobic respiration, fruit quality, phosphofruckinase. 


\section{Introduction}

Mango, a tropical fruit of great economic importance, is generally harvested green and then commercialized after a period of storage (Elhefni, 2011). Since mangoes are generally harvested at a mature-green stage, post-harvest changes are principally concerned with events associated with ripening and senescence, and with the effects of postharvest handling techniques (Mathieu and Jacques, 2007 and Pantastico et al., 1984).

A controlled atmosphere (CA) is an agricultural storage method. An atmosphere in which oxygen $\left(\mathrm{O}_{2}\right)$, carbon dioxide $\left(\mathrm{CO}_{2}\right)$ and nitrogen $\left(\mathrm{N}_{2}\right)$ concentration as well as temperature and humidity are regulated (Electronic link). CA can be used as supplemental treatments to keep fresh fruits within their optimum ranges of temperature and relative humidity to extend their postharvest-life (Kader, 1994). Optimal CA conditions lower respiration and ethylene production rates reduce ethylene action, delay ripening and senescence, retard growth of decaycausing pathogens, and control insects. On the other hand, CA conditions unfavorable to a given fruit can induce physiological disorders, enhance susceptibility to decay, and shorten shelf-life following removal from CA conditions. Generally, the longer storage duration either in air or in optimal CA conditions, the shorter shelf-life during subsequent marketing (Kader, 2003). Much research has been directed toward determination of the optimum CA conditions for a large numbers of fruits and vegetables and specific cultivar of each commodity (Richardson and Meheriuk, 1982).

Lowering the $\mathrm{O}_{2}$ levels around fruits and vegetables reduces their respiration rate in proportion to the $\mathrm{O}_{2}$ concentration, but a minimum of about $1-3 \% \mathrm{O}_{2}$, depending on the commodity, is required to avoid a shift from aerobic to anaerobic respiration. Under such respirations, the glycolytic pathway replaces the Krebs cycle as the main source of the energy needed by the plant tissues. Pyruvic acid is no longer oxidized but is decarboxylated to form acetaldehyde, $\mathrm{CO}_{2}$ and, ultimately, ethanol; this results in development of off flavors and tissues breakdown (Kader, 1986). 
Elevated $\mathrm{CO}_{2}$ concentration also reduces the respiration rate of fresh fruits and vegetables, but above a level of about $20 \%$ or higher, depending on the commodity and the $\mathrm{O}_{2}$ concentration, $\mathrm{CO}_{2}$ can result in accumulation of ethanol and acetaldehyde within the tissues (Kader, 1986).

Generally, very low levels of $\mathrm{O}_{2}$ and/or very high levels of $\mathrm{CO}_{2}$ can induce a shift from aerobic to anaerobic respiration, and can stimulate products of fermentation such as acetaldehyde and alcohol (Yahia et al., 1992).

Glycolysis is the basis of both anaerobic respiration and aerobic respiration, and it occurs in nearly all organisms. It is regulated by three enzymes catalyzing nonequilibrium reactions: Hexokinase, phosphofructokinase, and pyruvate kinase.

The conversion of fructose- 6-phosphate (F6P) to fructose-1,6bisphosphate $\left(\mathrm{F}-1,6-\mathrm{P}_{2}\right)$ with the concomitant hydrolysis of adenosine triphosphate (ATP) represents the first irreversible step specific for glycolysis. This reaction, catalyzed by 6-phosphofructo-1-kinase (PFK-1; phosphofructokinase-1, EC 2.7.1.11), is subjected to tight control, thus rendering it a critical regulatory point of the glycolytic flux (Hofmann, 1976 and Heinrich et al., 1977). PFK is an important regulatory enzyme and is a key element of control in the glycolytic pathway and is also subject to feedback control. It acts as an indicator of the energy status of the cell.

Temperature management is the most critical factor in the management of ripening in mature-green mangoes. Ripening is retarded when mangoes are held above $30^{\circ} \mathrm{C}$. Mature-green mangoes can be held at 10 to $13^{\circ} \mathrm{C}$ for 14 to 28 days (Paull and Chen, 2004). Ripe mangoes can be held at 10 to $13^{\circ} \mathrm{C}$ for up to one week. Being a tropical fruit, mangoes are subject to chilling injury if held below $13^{\circ} \mathrm{C}$ for mature green mangoes, and below $10^{\circ} \mathrm{C}$ for partially ripe mangoes (Kader and Mitcham, 2008). Ripe mangoes can be held in air storage at $10^{\circ} \mathrm{C}$ for a few days without chilling injury.

The objective of this work was to study the effect of controlled atmosphere storage of mango at $13^{\circ} \mathrm{C}$ on the activity of PFK and on fruit quality. 


\section{Materials and Methods}

\section{Fruit Materials}

This study was carried out on mango fruits (Mangifera indica L.) cv. Keitt. The fruits were harvested from a private mango orchard located at Cairo-Alexandria desert road El Kilo 84, Egypt. The trees had the same age and were homogenous in their morphology, besides received the standard horticultural care which was adapted in the area. Fruits were picked using a small clipper, and packed in carton boxes. Fruit were harvested at green mature stage and taken directly to post-harvest laboratory in Horticulture Department, Faculty of Agriculture, Zagazig University, it takes 4 hours. All fruits washed with regular tap water and soap and then rinsed with water to remove the residue of soap, dipped in $1000 \mathrm{ppm}$ Imazalil as a disinfectant for 5 minutes, then, air dried. A final sorting was done to recheck the fruits for any defects which were not detected at first sorting.

\section{Controlled Atmosphere Storage}

Completely randomized design was used where the four treatments were:

1- Storing fruits at $13^{\circ} \mathrm{C}$ under $\mathrm{CA}$ conditions of $\left(3 \% \mathrm{O}_{2}+6 \% \mathrm{CO}_{2}+\right.$ $91 \% \mathrm{~N}_{2}$ ).

2- Storing fruits at $13{ }^{\circ} \mathrm{C}$ under $\mathrm{CA}$ conditions of $\left(6 \% \mathrm{O}_{2}+6 \% \mathrm{CO}_{2}+\right.$ $88 \% \mathrm{~N}_{2}$ ).

3- Storing fruits at $13{ }^{\circ} \mathrm{C}$ under $\mathrm{CA}$ conditions of $\left(6 \% \mathrm{O}_{2}+9 \% \mathrm{CO}_{2}+\right.$ $85 \% \mathrm{~N}_{2}$ ).

4- Storing fruits in $\mathrm{PE}$ bags at $13^{\circ} \mathrm{C}$ (control).

60 uniform fruits were chosen at random for each treatment and packed in poly ethylene (PE) bags and jars. Samples of each treatment were randomly taken at weekly intervals to evaluate the effect of CA on storage period and on the activity of PFK.

CAS chambers were calibrated to establish the specified gas composition by a gas blending flow system. The gas blending system generated CA conditions using external supplies of gases from pressurized gas cylinders fitted with double-stage regulators and outlet controlling devices. These outlets were connected to the inlet flexible 
pipes that were inserted into the jars in which the mangoes were stored. The gas mixtures were humidified by bubbling through water before entering the jars containing the fruit.

Fruits were then stored at $13^{\circ} \mathrm{C}$, and evaluated every 7 days for total soluble solids (TSS), titratable acidity (TA), $\mathrm{pH}$, weight loss, firmness, and respiration rate. Wedge-shaped slice (approximate $5 \mathrm{~g}$ ) was removed from each fruit in the replicates and the pooled sample was passed through an electric juicer for the measurement of (TSS) and (TA) by refractometer and titration, respectively. The fruits were weighed before storage to obtain the initial weight, and then weighed after each period of storage as well as after shelf life period. Weight loss was determined as percentage of the initial weight. The $\mathrm{pH}$ was measured using a $\mathrm{pH}$ meter (style Hanna 8514). Firmness was measured on two pared sides of each fruit using a Push Pull dynamometer (Model FD 101). To measure respiration rate, $\mathrm{CO}_{2}$ output was recorded by titration and respiration rate was calculated as $\mathrm{mg} \mathrm{CO}_{2} \mathrm{~kg}^{-1} \mathrm{~h}^{-1}$ (Schirra, 1992).

\section{Preparation of PFK Extract}

Preparation of PFK extract was performed as described by (Gyulakhmedov et al., 2006). Sections were cut from five fruits and peeled. Middle samples were taken from 2-mm-thick parenchymal tissue. The samples were minced in an ice-cooled porcelain mortar and homogenized in a medium containing $25 \mathrm{mM}$ Tris-HCI $\mathrm{pH} 8.5,5 \mathrm{mM}$ EDTA, $2.5 \mathrm{mM} \mathrm{MgCI} 2,10 \mathrm{mM}$ 2-mercaptoethanol, $10 \mathrm{mM}$ Cis, $2 \%$ polyvinyl pyrrolidone (PVP-40), and $0.5 \%$ BSA. The ratio between the tissue and the extraction buffer was 1: $3 \mathrm{v} / \mathrm{v}$. The homogenate was filtered into an ice-cooled beaker through a double layer of nylon. The filtrate was centrifuged at $10000 \mathrm{~g}$ for $5 \mathrm{~min}$. The sediment was discarded, and the precipitate was used as a crude PFK preparation.

\section{Assay of PFK Enzyme}

Quantification of PFK enzyme was analyzed by using commercial quantitative immunoassay kits for PFK (Uscn Life Science \& Technology Company, PFK ELISA kit; R\&D systems, Japan). Values of $\mathrm{PFK}$ are assigned in $(\mathrm{ng} / \mathrm{mL})$.

\section{Statistical Analysis}

Complete randomized design was used. New Least Significant Difference (new LSD) at 5\% level was calculated to compare between 
treatments mean. Statistical analysis was determined using Statgraphics plus 5.1 statistical package software (Statpoint Technologies, Inc., United States) and Microsoft Excel.

\section{Results}

Overall accessibility ratings of fruits stored in CA were lower than those of fruits stored in the air.

\section{Effect of (CAS) on PFK Activity}

There were significant differences in the activity of PFK as compared with control under (CAS) after 5 weeks of storage which continued until the end of storage, Fig.1.

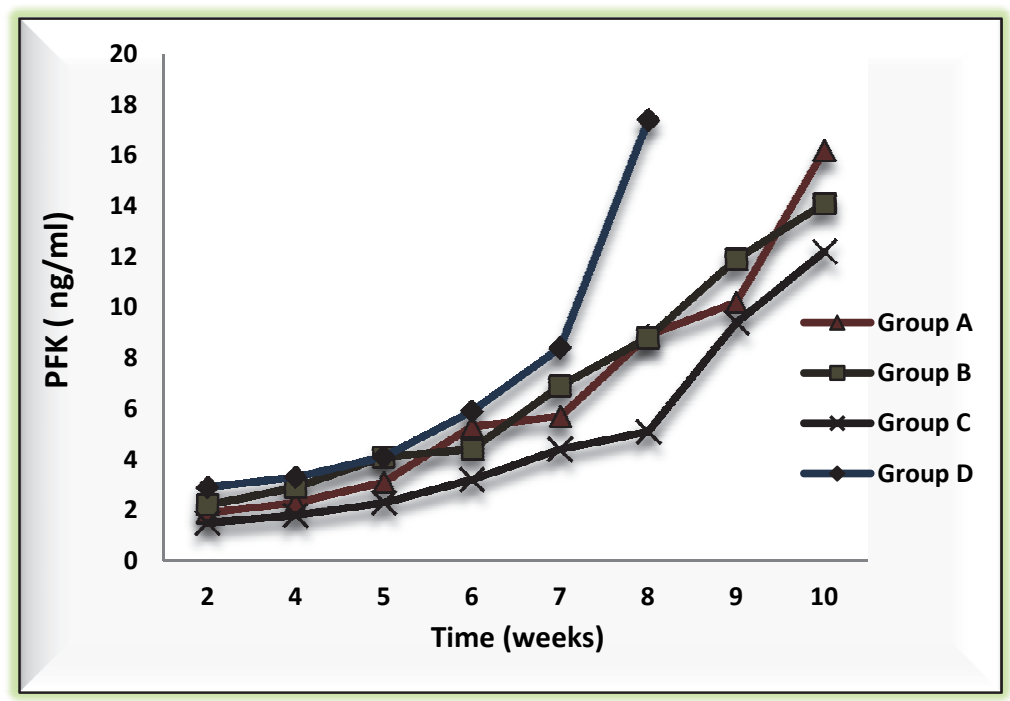

New LSD at $0.05=1.83$

Fig. 1. Phosphofructokinase (PFK) @ $13^{\circ} \mathrm{C}$ after storage under the controlled atmosphere. A: $\left(3 \% \mathrm{O}_{2}+6 \% \mathrm{CO}_{2}+91 \% \mathrm{~N}_{2}\right)$, B: $\left(6 \% \mathrm{O}_{2}+6 \% \mathrm{CO}_{2}+88 \% \mathrm{~N}_{2}\right), \mathrm{C}:\left(6 \% \mathrm{O}_{2}+9 \% \mathrm{CO}_{2}+85 \% \mathrm{~N}_{2}\right)$ and D: control (air)

\section{Effects of (CAS) on Ripening and Respiration Rates}

Fruits exposed to CA used in this work remained greener and more firm than those in the air, (Fig. 2). Flesh firmness of fruit kept in air was significant decreased very rapidly from $1960.0(\mathrm{~g} / \mathrm{cm} 2)$ to 1074.0 $(\mathrm{g} / \mathrm{cm} 2)$ after 4 weeks of storage, and to $289.17(\mathrm{~g} / \mathrm{cm} 2)$ after 6 weeks (New LSD at $0.05=74.87$ ). The flesh firmness of fruits which were kept under (CAS) also decreased, but it was in the air higher than them. 


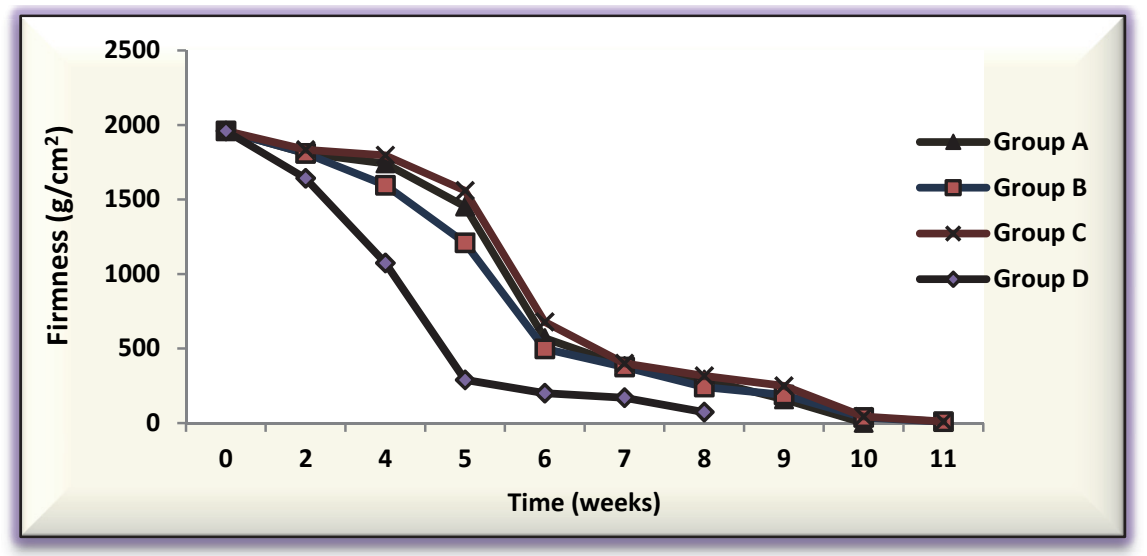

New LSD at $0.05=74.87$

Fig. 2. Flesh firmness of mangoes $@ 13^{\circ} \mathrm{C}$ after storage under the controlled atmosphere. A: $\left(3 \% \mathrm{O}_{2}+6 \% \mathrm{CO}_{2}+91 \% \mathrm{~N}_{2}\right), \mathrm{B}:\left(6 \% \mathrm{O}_{2}+6 \% \mathrm{CO}_{2}+88 \% \mathrm{~N}_{2}\right), \mathrm{C}:\left(6 \% \mathrm{O}_{2}+9 \% \mathrm{CO}_{2}+85 \% \mathrm{~N}_{2}\right)$ and D: control (air)

The storage of fruits under the $\mathrm{CA}$ resulted in a significant reduction in the respiration rate and in curtailment of the climacteric respiratory rise that accompanies ripening of mango fruit, Fig. 3.

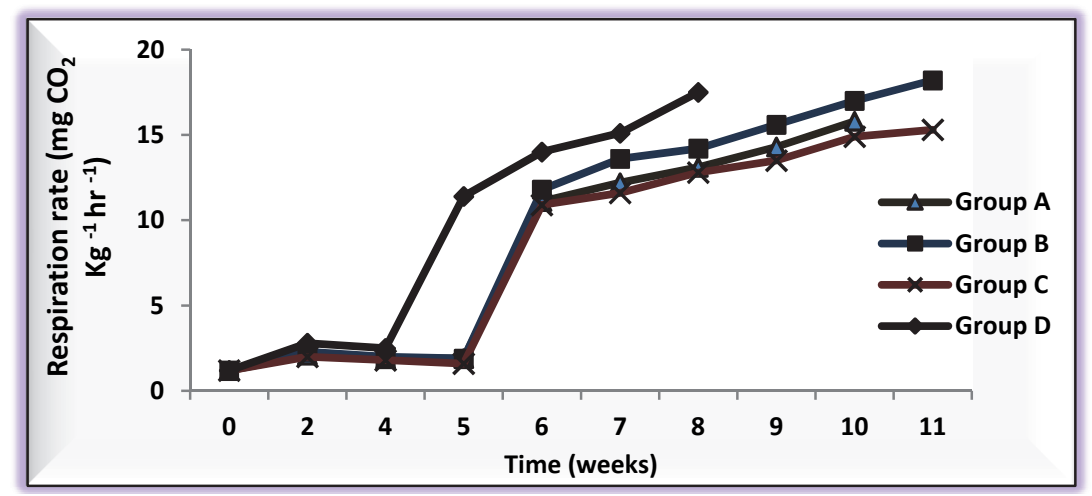

New LSD at $0.05=0.65$

Fig. 3. Respiration rate of mangoes after storage under the controlled atmosphere. A: $\left(3 \% \mathrm{O}_{2}+6 \% \mathrm{CO}_{2}+91 \% \mathrm{~N}_{2}\right)$, B: $\left(6 \% \mathrm{O}_{2}+6 \% \mathrm{CO}_{2}+88 \% \mathrm{~N}_{2}\right), \mathrm{C}:\left(6 \% \mathrm{O}_{2}+9 \% \mathrm{CO}_{2}+85 \% \mathrm{~N}_{2}\right)$ and D: control (air)

\section{Effects of (CAS) on Total Soluble Solids Content (TSS), Titratable Acidity (TA) and $\mathrm{pH}$}

No significant changes in TSS; (New LSD at $0.05=0.53$ ), TA; (New $L S D$ at $0.05=0.07)$ and $\mathrm{pH}$; (New LSD at $0.05=0.06)$ between fruits kept in the air and those kept under CA conditions were observed, Fig. 4. 


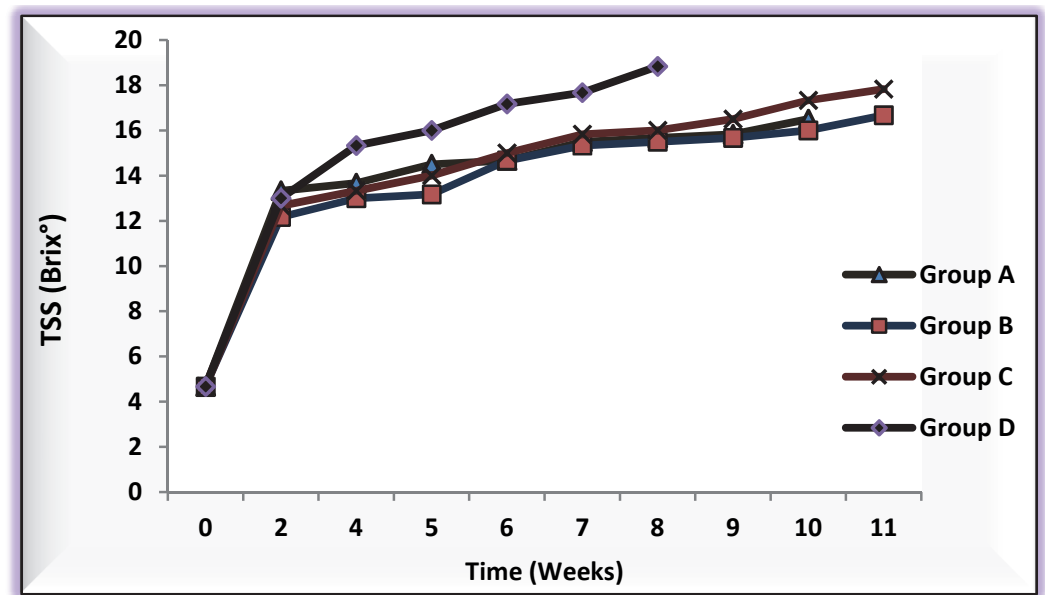

New LSD at $0.05=0.53$

Fig. 4. Total soluble solid contents of mangoes $@ 13^{\circ} \mathrm{C}$ after storage under the controlled atmosphere.

A: $\left(3 \% \mathrm{O}_{2}+6 \% \mathrm{CO}_{2}+91 \% \mathrm{~N}_{2}\right)$, B: $\left(6 \% \mathrm{O}_{2}+6 \% \mathrm{CO}_{2}+88 \% \mathrm{~N}_{2}\right), \mathrm{C}:\left(6 \% \mathrm{O}_{2}+9 \% \mathrm{CO}_{2}+85 \% \mathrm{~N}_{2}\right)$ and D: control (air)

\section{Effects of (CAS) on Water Loss}

Fruits under the CA had a significant less water loss than fruits which were kept in the air (New LSD at $0.05=1.19)$, Fig.5. After 8 weeks of storage under the CA conditions mangoes lost $2.35 \%$ to $2.86 \%$ of their weight, while in the air fruits lost $9.18 \%$ of their weight.

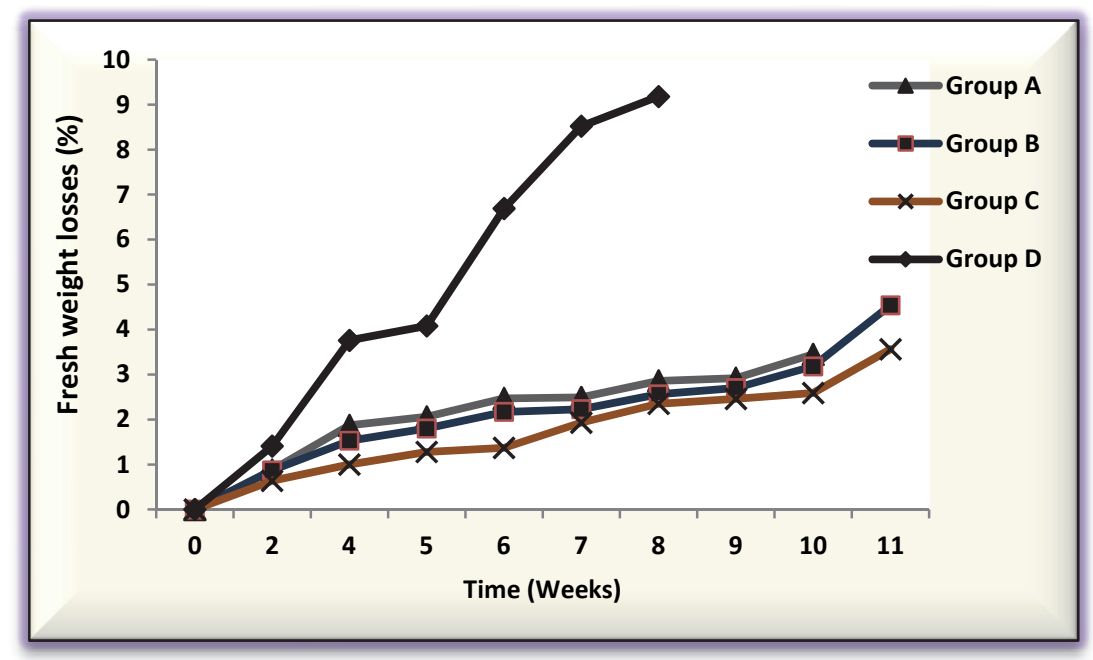

New LSD at $0.05=1.19$

Fig. 5. Water loss of mangoes after storage under the controlled atmosphere.

A: $\left(3 \% \mathrm{O}_{2}+6 \% \mathrm{CO}_{2}+91 \% \mathrm{~N}_{2}\right), \mathrm{B}:\left(6 \% \mathrm{O}_{2}+6 \% \mathrm{CO}_{2}+88 \% \mathrm{~N}_{2}\right), \mathrm{C}:\left(6 \% \mathrm{O}_{2}+9 \% \mathrm{CO}_{2}+85 \% \mathrm{~N}_{2}\right)$ and D: control (air) 


\section{Discussion}

The storage of fruits under the $\mathrm{CA}$ at $13^{\circ} \mathrm{C}$ retarded ripening and did not affect the quality attributes of Keitt mango. (CAS) reduced water loss but it did not decrease the vitamin $\mathrm{C}$ content (data not shown). Fruits did not exhibit external or internal injury, no off-flavors and had an acceptable sensory quality.

In order to avoid the risk of chilling injury to the fruit, it would be preferable to hold mature-green mangoes or mangoes at the breaker stage in a controlled atmosphere chamber with $4 \% \mathrm{O}_{2}$ (with the balance of the atmosphere being $\mathrm{N}_{2}$ ) and a temperature of $15^{\circ} \mathrm{C}$ than in a normal air environment at $10^{\circ} \mathrm{C}$ when attempting to delay ripening (Kader and Mitcham, 2008).

Ripening and senescence rates in many climacteric fruits like mangoes, can be affected by control of the availability of $\mathrm{O}_{2}$ and $\mathrm{CO}_{2}$ to the fruit during respiration and that these two compounds can have a significant inhibitory effect on ability of ethylene to initiate ripening (Ben-Yehoshua et al., 2005).

Storage of fruits and vegetables in $5-20 \% \mathrm{CO}_{2}$ cause changes in the activities of specific enzymes of the respiratory metabolism and may have an uncoupling effect on oxidation phosphorylation (Frenkel and Patterson, 1977).

The activity of PFK reduced under (CAS). This reduction by elevated $\mathrm{CO}_{2}$ could result from an inhibition of PFK synthesis or by inactivation of preexisting PFK. Regulation of glycolysis by PFK depends to a great extent on $\mathrm{pH}$ (Turner and Turner, 1980). Theoretical calculations and experimental data indicate that $\mathrm{CO}_{2}$ concentrations $>5 \%$ will generally lower intracellular $\mathrm{pH}$ (Bown, 1985). High $\mathrm{CO}_{2}$ concentrations may allow certain intermediates and cofactors to accumulate to a point where secondary reactions can take place. $\mathrm{CO}_{2}$ can also have a direct effect on metabolic activities distinct from that mediated by changes in $\mathrm{pH}$, where some proteins and complexes are known to dissociate and can be fractionated in the presence of $\mathrm{CO}_{2}$ (Mitz, 1979).

Rapid and substantial increases in the levels of F-1,6- $\mathrm{P}_{2}$ and reduction in the levels of F-6-P have been shown to accompany the rise in respiration that occurs during ripening of climacteric fruit (Nair and 
Darak, 1981). In all these cases the changes were attributed to an activation of PFK, which enhanced glycolysis and consequently respiration. By analogy, the reduction in PFK activity that we observed in our study, suggest that PFK is a controlling point in the glycolytic pathway and are affected by (CAS). There was a reduction of PFK and PFP activities, and accumulation of F-1,6- $\mathrm{P}_{2}$ and F-6-P in "Bartlett" bears stored in $10 \% \mathrm{CO}_{2}$ for up to 4 days at $20{ }^{\circ} \mathrm{C}$ (Kerbel et al., 1988).

The storage life of mangoes can be extended by holding the fruit in an environment with 3 to $5 \% \mathrm{O}_{2}$ and 5 to $10 \% \mathrm{CO}_{2}$, at 7 to $9{ }^{\circ} \mathrm{C}$ and $90 \%$ relative humidity atmosphere. They note that mango cultivars respond differently to $\mathrm{CA}$ storage, and that ripening delays provided may be minor (several days) and not economically advantageous in all situations (Paull and Chen 2004). The best CA for long-term storage of "Keitt" mango at $13{ }^{\circ} \mathrm{C}$ is $\left(5 \% \mathrm{O}_{2}+5 \% \mathrm{CO}_{2}+90 \% \mathrm{~N}_{2}\right)$, although it did not result in any significant advantage (Hatton and Reeder 1965). There were no significant benefits during storage of "Alfonso" mangos in atmosphere containing $\left(2 \% \mathrm{O}_{2}+8 \% \mathrm{CO}_{2}\right)$, or $\left(5 \% \mathrm{O}_{2}+10 \% \mathrm{CO}_{2}\right)$ (Spalding, 1977). However, "Haden" mangos have been stored for 6 weeks in $2 \% \mathrm{O}_{2}$ with $1 \%$ or $5 \% \mathrm{CO}_{2}$. Based on studies with Florida mango cultivars, the optimal range of $\mathrm{O}_{2}$ is 3 to $5 \%$ and $\mathrm{CO}_{2}$ is 5 to $10 \%$ in modified or controlled atmospheres (Bender et al., 2000, 2000a, 2000b, Kim et al., 2007 and Yahia, 2006). Mangos tolerate short exposures to insecticidal atmospheres with very low $\mathrm{O}_{2}$ and elevated $\mathrm{CO}_{2}$ (Yahia and VasquezMoreno, 1993). However, exposure of mature-green mangos to $\mathrm{O}_{2}$ levels below $2 \%$ and/or $\mathrm{CO}_{2}$ levels above $10 \%$ for longer than a few days may induce skin discoloration, grayish or pale flesh color, uneven ripening, and off-flavor development due to fermentative metabolism (accumulation of acetaldehyde and ethanol) (Kader 2008).

\section{Conclusion}

The atmosphere used in this work resulted in modification of the activity of PFK. In addition, the storage of fruits under the CA retarded ripening and did not affect the quality attributes of Keitt mango. These results indicate a potential for the application of CA for post-harvest ripening control of mango cv. Keitt. The optimal CA for long-term storage of "Keitt" mango at $13{ }^{\circ} \mathrm{C}$ is $\left(3 \% \mathrm{O}_{2}+6 \% \mathrm{CO}_{2}+91 \% \mathrm{~N} 2\right)$; under 
these conditions the storage life of mango can be extended up to 10 weeks.

\section{References}

Bender, R.J., Brecht, J.K., Baldwin, E.A. and Malundo, T.M.M. (2000). Aroma volatiles of mature-green and tree-ripe 'Tommy Atkins' mangoes after controlled atmosphere vs. HortScience 35: 684-686.

Bender, R.J., Brecht, J.K., Sargent, S.A. and Huber, D.J. (2000a). Mango tolerance to reduced oxygen levels in controlled atmosphere storage. J. Amer. Soc. Hort. Sci. 125: 707-713.

Bender, R.J., Brecht, J.K., Sargent, S.A. and Huber, D.J. (2000b). Low temperature controlled atmosphere storage for tree-ripe mangoes (Mangifera indica L.). Acta Hort. 509: 447-458.

Ben-Yehoshua, S., Beaudry, R.M., Fishman, S., Jayanty, S. and Mir, N. (2005). Modified atmosphere packaging and controlled atmosphere storage. In: Environmentally friendly technologies for agricultural produce quality. Ben-Yehoshua, S. Ed. Taylor and Francis Group LLC. Boca Raton, FL, USA. Chapter 4.

Bown, A.W. (1985). $\mathrm{CO}_{2}$ and intracellular pH. Plant Cell Environ. 8: 459-465.

Electronic link: (http://en.wikipedia.org/wiki/Controlled atmosphere)

Elhefni, A.A. (2011). Mango- Postharvest Physiology, Compositional Changes during Ripening, and its Healthy Benefits and Curative Properties. Metabolizm Jurnali.12(2): 21-33.

Frenkel, C. and Patterson, M.E. (1977). Metabolic effects of $\mathrm{CO}_{2}$ in 'Bartlett' pears, p. 108-115. In: D.H. Dewey (Ed.). Controlled atmospheres for the storage and transport of perishable agricultural commodities. Hort. Report No. 28, Michigan State Univ., East Lansing, MI, U. S. A.

Gyulakhmedov, S.G., Omarov, Y.A., Mamedov, Z.M. and Kuliev, A.A. (2006). Isolation and Study of Active ATP-dependent Phosphofructokinase from Apple Fruits Pyrus domestica Borkh. Applied biochemistry and microbiology. 42(5): 468-471.

Hatton, T.T. and Reeder, W.F. (1965). Controlled atmosphere storage of Keitt mangoes. Proceeding of the American Society for Horticultural Science, 10: 114-119.

Heinrich, R., Rapoport, S.M. and Rapoport, T.A. (1977). Metabolic regulation and mathematical models. Prog. Biophys Mol Biol 32: 1-82.

Hofmann, E. (1976). The significance of phosphofructokinase to the regulation of carbohydrate metabolism. Rev Physiol. Biochem. Pharm 75: 1-69.

Kader, A.A. (1986). Biochemical and physiological basis for effects of controlled and modified atmospheres on fruits and vegetables. Food.Technol. 40: 99-104.

Kader, A.A. (1994). Modified and controlled atmosphere storage of tropical fruits. ACIAR Proceedings No. 50: 239-249.

Kader, A.A. (2003). A Summary of CA Requirements and Recommendations for Fruits Other than Apples and Pears. Acta Hort. (ISHS) 600: 737-740.

Kader, A.A. (2008). Mangoes Recommendations for Maintaining Postharvest Quality. In: Fruit Ripening and Ethylene Management. 50-51. Univ. Calif. Postharvest Technology Research and Information Center Publication Series \#9.

Kader, A.A. and Mitcham, B. (2008). Optimum Procedures for Ripening Mangoes. In: Fruit Ripening and Ethylene Management: 47-48. Univ. Calif. Postharvest Technology Research and Information Center Publication Series \#9.

Kerbel, E.L., Kader, A.A. and Romani, R.J. (1988). Effects of elevated $\mathrm{CO}_{2}$ concentrations on glycolysis in intact 'Bartlett' pear fruit. Plant Physiol. 86: 1205-1209.

Kim, Y., Brecht, J.K. and Talcott, S.T. (2007). Antioxidant phytochemicals and fruit quality changes in mango (Mangifera indica L.) following hot water immersion and controlled atmosphere storage. Food Chem. 105: 1327-1334. 
Mathieu, L. and Jacques, J. (2007). An overview of preharvest factors influencing mango fruit growth, quality and postharvest behavior. Braz. J. Plant Physiol. 19(4): 287-298.

Mitz, M.A. (1979). $\mathrm{CO}_{2}$ biodynamics: a new concept of cellular control. Journal of Theoretical Biology, 80: 537-551.

Nair, P.M. and Darak, B.G. (1981). Identification of multiple forms of phosphofructokinase in ripening Dwarf Cavendish banana. Phytochemistry 20: 605-609.

Pantastico, E.B., Lam, L.R., Ketsa, S., Yuniarti, Y. and Kosittrakul, S. (1984). Mango fruit development, post-harvest physiology and marketing in ASEAN. In: ASEAN Food Handling Bureau, Mendoza, D.B. Jr. and Wills, R. B. H. (eds.). Kuala Lumpur, pp. 41- 43.

Paull, R.E. and Chen, C.C. (2004). Mango. In: Gross K.C., Wang C.Y. and Saltveit M. (eds), The Commercial Storage of Fruits, Vegetables and Florist and Nursery Stocks. A draft version of the forthcoming revision to USDA, Agriculture Handbook 66 on the website of USDA, Agricultural Research Service.

Richardson, D.G. and Meheriuk, M. (Eds.). (1982). Controlled Atmospheres for Storage and Transport of Perishable Agricultural Commodities, Timber Press, Beaverton, ORo

Schirra, M. (1992) behavior of Star Ruby grapefruits under chilling and nonchilling storage temperatures. Postharvest. Biol. Technol. 2: 315-327.

Spalding, D.H. (1977). Current recommendation for transport and storage of tropical fruits, p. 242-249 In: D.H. Dewey (Ed.). Controlled atmospheres for the storage and transport of perishable agricultural commodities. Hort. Report No. 28, Michigan State Univ., East Lansing, MI, U. S. A.

Turner, J.F. and Turner, D.H. (1980). The regulation of glycolysis and pentose phosphate pathway, p. 279-316. In: D.D. Davies (ed.). The biochemistry of plants: A comprehensive treatise. Vol. 2. Academic Press, New York, pp 279-316.

Yahia, E.M., Rivera, M. and Hernandez, O. (1992). Response of papaya to short-term insecticidal oxygen atmosphere. Journal of the American Society for Horticultural Science, 117(1): 96-99.

Yahia, E.M. (2006). Modified and controlled atmospheres for tropical fruits. Stewart Postharvest Review. 5(6): 10.

Yahia, E.M. and Vasquez-Moreno, l. (1993). Responses of mango to insecticidal oxygen and carbon dioxide atmospheres. Lebersm. Wiss. u. Technol. 26: 42-48. 


\section{أثز التخزين تحت الجو المتحكم فيه على النشاط الإنزيمى} لإنزيم الفسفوفركتوكينيز (Mangifera Indica L) في ثمار فاكهة

$$
\text { المانجو صنف كيت }
$$

أحمد عبد المنعم الحفني، و صاحب جول أحمدوف، و السيد مجدي الحفناوي'،

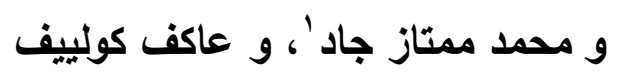
كلية البيولوجيا، قسم الكبيمياء الحيوية والثكنولوجيا الحبوية، جامعة باكو الحكومية، أذربيجان ' 'كلية الزراعة، قسم البساتين، جامعة الزقازيق، جمهورية مصر العربية العبدن

الكستخلص. يتم تنظيم تركيز كل مـن الأكسجين، وثناني أكسيد

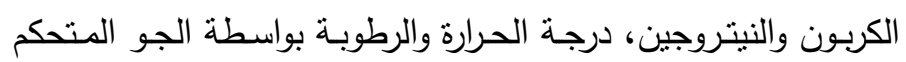

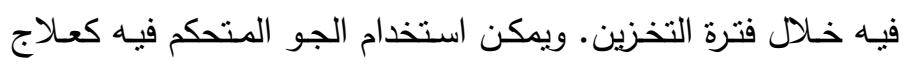

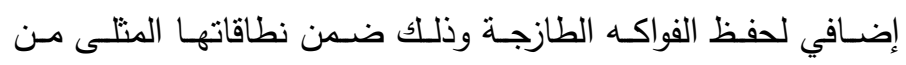
الرطوبة النسبية ودرجات الحرارة وذلك لزيادة فترة بقائها بعد الحصاد. لكاديا.

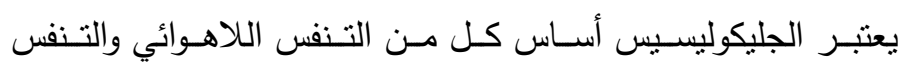

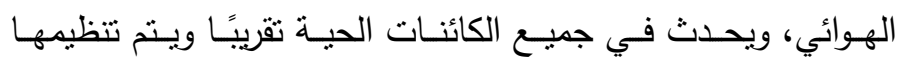

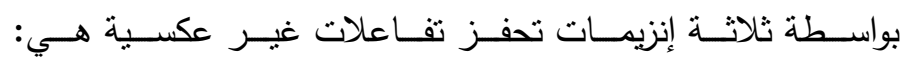

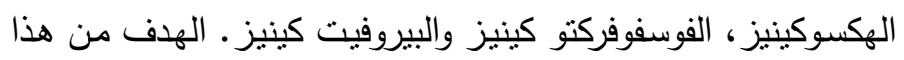

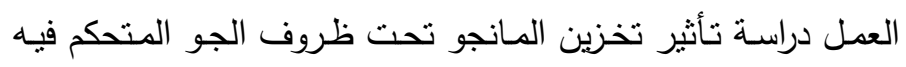

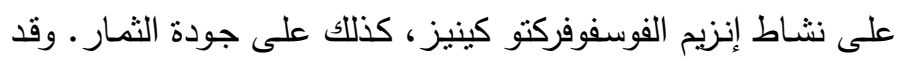

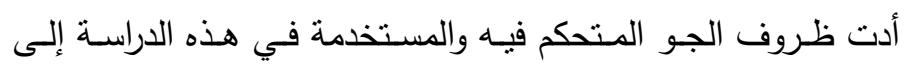

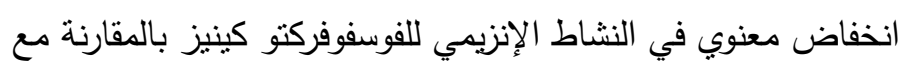

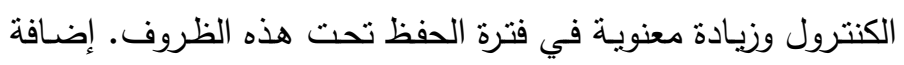


إلى ذلك، كان هناك انخفاض في إنتاج ثاني أكسيد الكربون. وتشير

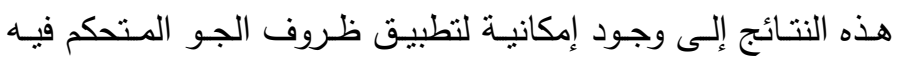
للتحكم في عمليـة نضـج المـانجو بعد الحصـاد. الجو المتحكم فيـه فئه

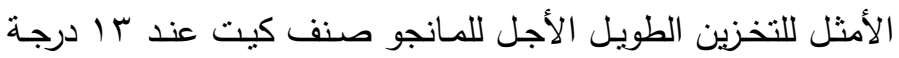

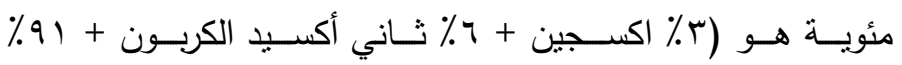
نيتروجين)، ويمكن في ظل هـــ الظـروف أن تمتـد فترة التخزين للمانجو لتصل إلى • (1 أسابيع. الكلمات الدالة: التخزين تحت الجو المـتحكم فيـه، المـانجو، التنفس

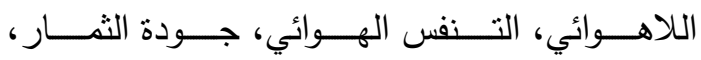

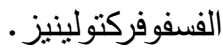

